\title{
Job Demands-Resources and Personal Resources as Risk and Safety Factors for the Professional Burnout Among University Teachers
}

\author{
Aurelija Stelmokienè ${ }^{1}$, Giedrè Genevičiūtė-Janonè ${ }^{2}$, Loreta Gustainiené $\dot{e}^{3}$, \\ Kristina Kovalčikienè $\dot{e}^{4}$
}

1 Vytautas Magnus University, Department of Psychology, Jonavos g. 66, LT-44191, Kaunas, Lithuania, aurelija.stelmokiene@vdu.lt

2 Vytautas Magnus University, Department of Psychology, Jonavos g. 66, LT-44191, Kaunas, Lithuania, giedre.geneviciute-janone@vdu.lt

3 Vytautas Magnus University, Department of Psychology, Jonavos g. 66, LT-44191, Kaunas, Lithuania, loreta.gustainiene@vdu.lt;

4 Vytautas Magnus University, Department of Psychology, Jonavos g. 66, LT-44191, Kaunas, Lithuania, kristina.kovalcikiene@vdu.lt

\begin{abstract}
The study was oriented to identify the main risk and safety factors for the professional burnout among university teachers in Lithuania. 257 participants filled up a self-administered questionnaire in a cross-sectional survey. 42.8 percent of university teachers in Lithuania indicated that are often or permanently suffering from professional burnout. Quantitative and emotional demands alongside with perceived social support from a supervisor acted as risk factors, and personal resources and social support from colleagues - assafety factors for the professional burnout.
\end{abstract}

Keywords: professional burnout, job demands, personal resources, job resources, university teachers. 


\section{Introduction}

Higher educational institutions play a special role in the development of the human being as well as national economics. Universities are responsible for providing competitive human capital to meet future challenges and develop a competitive, dynamic, knowledge-based economy (Ishaq, Mahmood, 2017). Recently, higher education is facing many significant changes that influence well-being of academicians. Restructuration of universities, challenges related to the new generation of students, increasing work requirements, role conflict of a teacher-researcher, intensity of student contact hours are only a few stressors in a daily work of university teachers which could lead to the professional burnout (Puertas-Molero et al., 2018; Vesty et al., 2018; Xu, 2017) generally recognized as a result of the prolonged work stress.

Over the last four decades, professional burnout has become a serious issue that affects the well-being of employees from different professions, especially human service workers (Azeem, Nazir, 2008; Shaufeli, Leiter, Maslach, 2009). Many studies confirmed that teaching is one of the most stressful occupations among the human service professions because of the nature of working conditions, i. e. work overloads, frequent close contact with learners, high requirements, etc. (Barkhuizen, Rothmann, 2014; Antoniou, Ploumpi, Ntalla, 2013; de Heus, Diekstra; 1999; Johnson et al., 2005). According to previous literature, teachers burn out more easily than members of other social professions (Heus, Diekstra, 1999) and suffer from burnout more often than other white-collar workers (Schaufeli, Enzmann, 1998).

Burnout can be defined as a person's state of physical, emotional and mental exhaustion which is caused by a long-term involvement in emotionally demanding work situations (Harrison, 1999; Schaufeli, Greenglass, 2001). A burned-out employee loses enthusiasm, excitement and the essence of mission in his/her work (Azeem, Nazir, 2008). According to Maslach and Leiter (1999) a person burns out when he or she is facing a great workload with a lack of personal control, insufficient rewards for job performance, the breakdown in the working community, absence of fairness or value conflicts. Studies show that burnout negatively affects not only teacher's personal and professional competence (Maslach, 2017; Watts, Robertson, 2011), mental and physical health (Lath, 2010; Maslach, 2017), but also causes various consequences at a group and organizational levels: compromises productivity in the unit/ organization (Pishghadam et al., 2014; Watts, Robertson, 2011), affects students' development (Pu et al., 2017) and their motivation (Shen et al., 2015), increases job dissatisfaction, absenteeism, turnover of employees (Salvagioni et al., 2017; Swider, Zimmerman, 2010).

Moreover, university teachers' burnout becomes a serious concern due to its prevalence. For example, more than half of the university teachers in Ethiopia were experiencing high levels of burnout (Kebde, Gedfie, 2018). Lackritz (2004) found that over one-fourth of the university faculty members were experiencing a high level of emotional exhaustion in 
the United States. Visotskaya and colleagues (2015) identified that $46 \%$ of humanitarian subjects teachers in Russian universities had experienced exhaustion. The burnout level of the university academicians in Turkey was found to be on the average level (Toker, 2011). Unfortunately, there is a lack of research in Lithuania about the prevalence of burnout among university teachers. Therefore, a similar study would allow a deeper understanding of the current situation in this country.

The relevance of researching the problem of teachers' burnout is also reinforced by the current structural changes in the Lithuanian education system. Existing research results show that the biggest challenges for university teachers in Lithuania are high workload and discrepancies between teachers and university administration priorities for work activities (Bulotaitè, Pociūtè, Bliumas, 2008; 2012), peculiarities of the education system (i. e. education policy, constant university reforms, threat of restructuring), working conditions (i. e. work under fixed-term contracts, lack of time to prepare for lectures, poor classroom and laboratory equipment) (Pociūtè, Bulotaitè, Bliumas, 2012). This holds true for the work environment in the European organizations as well (Diener et al., 2017).

\section{Risk and safety factors for the professional burnout}

The analysis of risk and safety factors for the professional burnout among university teachers becomes more and more interesting to the researchers and practitioners that admit - occupational well-being is a crucial factor not only to human functioning but also to job performance (Bakker, Demerouti, 2018). Identification of these factors could help to propose recommendations how to deal with the ascending problem of university teachers' professional burnout. Recently Job Demands - Resources theory (Bakker, Demerouti, 2014, 2017) has become a leading approach in stress research (Dicke et al., 2018). According to this theory, job demands are aspects of a job that require additional efforts (physical and/ or psychological) from employees and could be related to their strain symptoms (e.g. burnout, stress, bad sleep, etc.). However, the costs of job demands can be reduced by personal and job resources. Both personal and job resources can buffer the impact of job demands on negative strain (Bakker, Demerouti, 2018).

Therefore, three levels of factors should be analysed when talking about the antecedents of professional burnout. The first level is a task that needs to be accomplished at work. Three main characteristics describe the task in the service sector: the amount of work (quantitative demands), the speed of work (work pace) and psychological aspect of work (emotional demands) (Rupert, Miller, Dorocial, 2015). The second level is a person who accomplishes those tasks at work. Personal resources could be general ones (e.g. optimism) and more related to work (e.g. occupational self-efficacy) (Bakker, Demerouti, 2018). They depend on a particular employee in the organization. The third level is a group or organization in which the employee accomplishes his/her tasks. Here, 
interpersonal relationships with colleagues and a leader (e.g. social support) are an important context (Bakker, Demerouti, 2018). In this situation the first - task - level could be a risk factor for the professional burnout and personal and interpersonal resources may act as safety factors (see Figure 1). More thorough analysis of each factor is presented in the sections below.

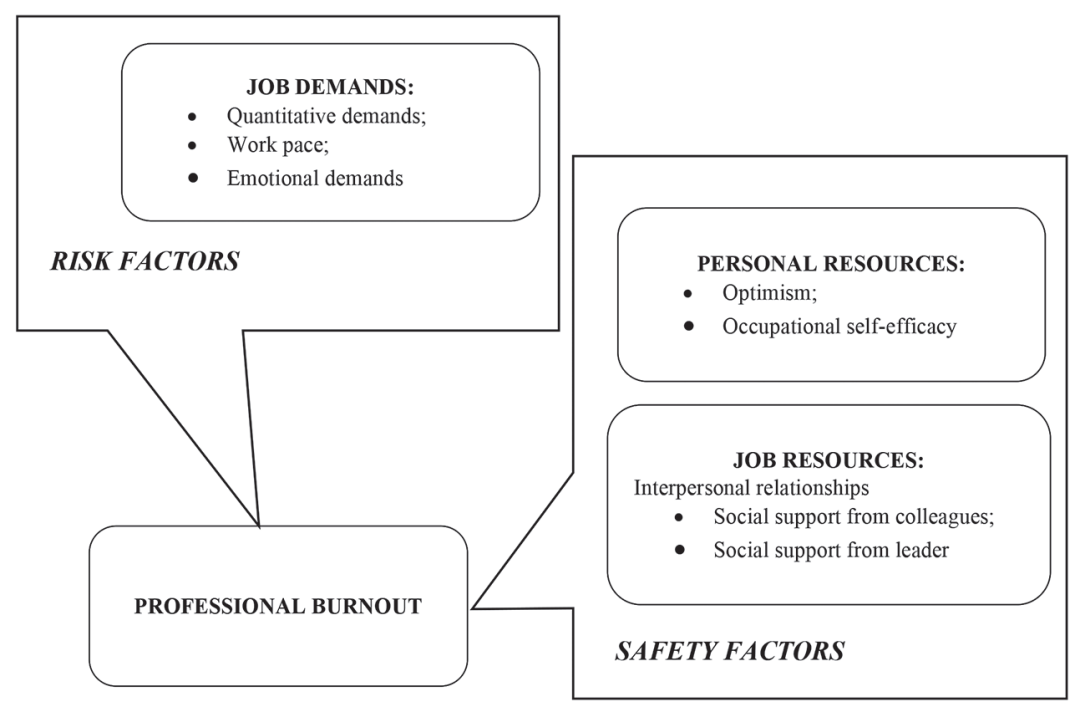

Figure 1. Risk and safety factors for the professional burnout among university teachers: a theoretical model

\section{Job demands}

Job demands are characterized as job characteristics that are related to the consumption of energetic resources and even energy depletion (Bakker, Demerouti, 2018). They may trigger a health impairment process: cause job strain and health complaints (Berthelsen, Hakanen, Westerlund, 2018; Bakker, Demerouti, 2017).The changing nature of work is related to the increase in emotional and psychological demands (Vegchel et al., 2004). It is true and really can be defined as a current challenge for academic workplaces that experience global and national changes (Mudrak et al., 2018). Emotional demands are defined as job demands that require sustained emotional efforts during the interaction with clients. Human interaction with different groups of "clients" is a central aspect in the education sector. However, research on the relationship between emotional demands and burnout is scarce. It's pity, because emotional demands are as important as quantitative ones when predicting burnout of employees in human service sector (Vegchel et al., 2004), especially, in higher education sector, where teachers have interactions with 
various groups of students (different age, socio-economic status, cultural background, expectations and aims, etc.).

Quantitative demands and work pace are classified as psychological demands (Vegchel et al., 2004). They are defined as psychological stressors involved in accomplishing tasks at work (Karasek, 1979 cited by Kristensen et al., 2004). Quantitative demands are related to the amount of work to be done in a limited time. When there is a mismatch between the amount of work and available time for it, an employee can experience stress (Kristensen et al., 2004). There is a pressure for the increased productivity at the global labor market that results in a pressure for faster work pace and longer working hours because an employee lacks time for the amount of work he or she needs to do. Therefore, not only extensity (number of working hours) is important, intensity (work pace) should also be considered as a significant factor in predicting health impairment (Kristensen et al., 2004). Teachers' work specifically is related to a lot of different responsibilities (teaching, scientific work, administrative duties, etc.) and a limited time to perform them with a demand to work fast.

Researchers confirm that the negative impact of job demands on mental and physical health are mediated by the increasing job burnout (Baka, 2015). Even longitudinal data about teachers' occupational well-being revealed significant direct effects of demands (classroom disturbances) on strain (Dicke et al., 2018). However, quantitative demands for university faculty had a relatively weak effect on experienced stress (Mudrak et al., 2018).

Therefore, we hypothesize that both emotional and psychological job demands are related to higher professional burnout among university teachers. Emotional demands have a stronger effect on professional burnout than psychological job demands.

\section{Safety factors: resources}

Conservation of resources (COR) theory "posits that stress occurs (a) when central or key resources are threatened with loss, (b) when central or key resources are lost, or (c) when there is a failure to gain central or key resources following significant effort" (Hobfoll et al., 2018, p. 104). Therefore, "people employ key resources not only to respond to stress, but also to build a reservoir of sustaining resources for times of future need" (Hobfoll et al., 2018, p. 104). Thus, it is equally important to take into consideration employees' general well-being in addition to their work-related well-being (Upadyaya, Vartiainen, Salmela-Aro, 2016). Within the context of occupational health psychology personal and work-related resources are distinguished. 


\section{Personal resources}

Personal resources refer to positive beliefs people hold about the environment (e.g. optimism) and their capability to deal with this environment in general (e.g. self-efficacy) and in the specific situations at work (e.g. occupational self-efficacy) (Bakker, Demerouti, 2017). Personal resources are expected to buffer the impact of job demands on the strain. However, more research is needed to confirm this relationship (Bakker, Demerouti, 2017).

Optimism is a facet of personality that is inherently cognitive in nature (i.e. expectancies regarding future outcome) (Carver, Scheier, 2014). Thus, optimists are people who expect good things to happen to them, and on the contrary, pessimists are the ones to expect bad things to happen to them (Carver, Schein, Segerstrom, 2010). Research findings indicate that optimism has been linked to better emotional well-being, more effective coping strategies, better outcomes in several areas of physical health, and better interpersonal relationships (Carver, Schein, Segerstrom, 2010). Dispositional optimism had a strong direct effect on perceptions of job resources as well as strong indirect effects (via job resources) on burnout in South African university teachers (Barkhuizen, Rothmann, van de Vijver, 2014). As a part of psychological capital (PsyCap), it also moderated the relationship between work-family conflict and burnout in Chinese university teachers $(\mathrm{Pu}, \mathrm{Hou}, \mathrm{Ma}$, Sang, 2017). Nevertheless, optimism remains to be underresearched in the context of professional burnout among European countries.

Self-efficacy construct represents Bandura's Social Cognitive Theory. It is conceived as "a dynamic set of self-beliefs that are linked to particular performance domains and activities" (Lent, 2005, p. 104). In this sense, self-efficacy can be understood as a belief in one's ability to perform the specific tasks required to succeed within a given domain (Bandura, 1977). Occupational self-efficacy is defined as a domain-specific self-efficacy and indicates "the competence that a person feels concerning the ability to successfully fulfill the task involved in his or her job" (Rigotti, Schyns, Mohr, 2008, p. 239). Occupational self-efficacy was found to be related to job satisfaction, work engagement (Schyns, Wolfram, 2008) as well as organizational citizenship behavior (Speier, Frese, 1997). Research findings suggest that, among others, self-efficacy is a significant indicator of personal resources and mediates the effect of perceived organizational support on emotional exhaustion (one of burnout components) (Karatepe, 2015). Longitudinal data about teachers' occupational well-being showed that self-efficacy buffered the demands-strain relationship (Dicke et al., 2018). Despite the mentioned research on optimism and self-efficacy, occupational self-efficacy in particular has got less attention in the context of professional burnout. Besides, it should be noted that burnout studies have mainly focused on the job, not personal resources (Rupert, Miller, Dorociak, 2015).

With reference to the literature review above, we hypothesize, that higher levels of personal resources, i.e. optimism and occupational self-efficacy, are related to lower levels of professional burnout among university teachers. 


\section{Job resources}

Job resources are those "physical, social, or organizational aspects of the job that (a) are functional in achieving work-related goals, (b) reduce job demands and the associated physiological and psychological costs, and (c) stimulate personal growth and development" (Xanthopoulou et al., 2007). In summary, these different aspects of the job both stimulate motivation to achieve goals and reduce impact of job demands to strain of employees (Bakker, Demerouti, 2017). Organizational support reflects employees' perceptions that the organization cares about their input and well-being (Eisenberger et al., 1997 cited by Pitichat et al., 2018). According to Organizational Support theory, perceived organizational support initiates a social exchange process wherein employees feel obligated to help the organization achieve its goals and objectives and expect that increased efforts on the organization's behalf will lead to greater rewards (Kurtessis et al., 2015). Employees make the judgement about the organization by considering social support both from leaders and coworkers. It is suggested that support from supervisors has a stronger impact on an employee well-being than that of a co-worker (Kurtessis et al., 2015).

The stress - buffering hypothesis states that social support protects employees from the pathological consequences of stressful experiences (Cohen, Wills, 1985 cited by Bakker, Demerouti, Euwema, 2005). The positive role of social support in burnout prevention has been recognized some decades ago (Maslach, Goldberg, 1998). Social support from colleagues and supervisor are key job resources in academic workplaces internationally (Mudrak et al., 2018). Perceived social support from coworkers enhanced the level of reported job performance and decreased the level of reported job stress among nurses (AbuAlRub, 2004).Similarly, social support from a supervisor may alleviate the influence of job demands on burnout and may also act as a protector against ill - health (Väänänen et al., 2003). Staff members of higher education institutions who perceive low job demands (overload) and high job resources (e.g. organizational support), are least likely to display burnout and ill health (Rothmann, Essenko, 2007). Still, findings of workplace support and professional burnout are complex and not very consistent (Rupert, Miller, Dorociak, 2015).

Based on the research presented above, our third hypothesis holds that social support from both colleagues and leaders are related to lower levels of professional burnout among university teachers. Moreover, social support from supervisors has a stronger impact on professional burnout than that of co-workers.

In summary it can be noted that our research investigated a hot topic of professional burnout - one of the main issues that affect the well-being of university teachers all over the world. The practical relevance of researching the problem of teachers' burnout is also reinforced by the changes Lithuanian higher education system and people in this system experience right now. Therefore, suggestions for intervention programs are very 
welcomed by the university leaders and Lithuanian government. The scientific novelty of this study can be based on two other issues. Firstly, we focus on the antecedents of professional burnout and include three levels of them into our analysis: task, person and group or organization. Moreover, we propose that some of these antecedents can work as safety and others - as risk factors for the professional burnout of university teachers and try to measure their integrative prognostic value.

Therefore, the current study was oriented to identify the main risk and safety factors for the professional burnout among university teachers with reference to the results of literature analysis and empirical quantitative research.

Specifically, this study aimed at:

1) developing a theoretical model of risk and safety factors for the professional burnout among university teachers;

2) evaluating the extent of university teachers' burnout in Lithuania;

3) testing a proposed theoretical model of the antecedents of professional burnout in practice using a cross sectional survey;

4) proposing directions for future research and practical recommendations.

\section{Methods}

Sample and data collection. 257 university teachers (88 males and 166 females, 3 persons did not indicate their gender) participated in a cross sectional quantitative on-line survey. Only 33 of them did not have a doctoral degree yet. The average age of participants was 46.42 years $(\mathrm{SD}=10.23)$. Their work experience at present organization ranged from 1 until more than 40 years $(\mathrm{M}=15.23, \mathrm{SD}=8.83)$ Teachers represented two universities in Lithuania.

Participants filled up a self-administered questionnaire. Voluntary participation in the research and confidentiality were guaranteed. The response rate was 23.31 percent.

Measures. Perceived job demands, as well as job resources and professional burnout, were measured with COPSOQ II (Copenhagen Psychosocial Questionnaire, National Centre for the Working Environment, 2007) scales. Additional two questionnaires were used for the measurement of personal resources: Occupational self-efficacy scale (Rigotti et al., 2008) and Life Orientation Test-Revised (Herzberg, Glaesmer, Hoyer, 2006). Detailed information about the instruments is presented in Table 1. 
Table 1

Information about the survey instruments

\begin{tabular}{|c|c|c|c|c|}
\hline Instrument & Scales & $\begin{array}{l}\text { Number of } \\
\text { statements }\end{array}$ & $\begin{array}{l}\text { Example of } \\
\text { statements }\end{array}$ & $\begin{array}{c}\text { Cronbach } \\
\text { alpha }\end{array}$ \\
\hline \multirow[t]{6}{*}{ COPSOQ II } & $\begin{array}{l}\text { Quantitative } \\
\text { demands }\end{array}$ & 4 & $\begin{array}{l}\text { Do you get behind with } \\
\text { your work? }\end{array}$ & .819 \\
\hline & Work pace & 3 & $\begin{array}{l}\text { Do you work at a high pace } \\
\text { throughout the day? }\end{array}$ & .889 \\
\hline & $\begin{array}{l}\text { Emotional } \\
\text { demands }\end{array}$ & 4 & $\begin{array}{l}\text { Is your work emotionally } \\
\text { demanding? }\end{array}$ & .779 \\
\hline & $\begin{array}{l}\text { Social support from } \\
\text { colleagues }\end{array}$ & 3 & $\begin{array}{l}\text { How often do you get help } \\
\text { and support from your } \\
\text { colleagues, if needed? }\end{array}$ & .866 \\
\hline & $\begin{array}{l}\text { Social support from } \\
\text { leader }\end{array}$ & 3 & $\begin{array}{l}\text { How often do you get help } \\
\text { and support from your } \\
\text { immediate superior, if } \\
\text { needed? }\end{array}$ & .938 \\
\hline & $\begin{array}{l}\text { Professional } \\
\text { burnout }\end{array}$ & 4 & $\begin{array}{l}\text { How often (during the } \\
\text { last } 4 \text { weeks) have you felt } \\
\text { worn out? }\end{array}$ & .937 \\
\hline $\begin{array}{l}\text { Occupational } \\
\text { self-efficacy scale }\end{array}$ & - & 6 & $\begin{array}{l}\text { I can remain calm when } \\
\text { facing difficulties in my } \\
\text { job because I can rely on } \\
\text { my abilities. }\end{array}$ & .843 \\
\hline $\begin{array}{l}\text { Life Orientation } \\
\text { Test - Revised }\end{array}$ & - & 6 & $\begin{array}{l}\text { In uncertain times, I usu- } \\
\text { ally expect the best. }\end{array}$ & .743 \\
\hline
\end{tabular}

\section{Results}

First of all, the analysis of research data was carried out to determine the prevalence of occupational burnout among university teachers in Lithuania. Based on the values of the answers in the professional burnout questionnaire where 1 means "never", 2 - "rarely", 3 - "sometimes", 4 - "often" and 5 - "always", a higher value showed a higher level of professional burnout in this sample. It was found that 42.8 percent of university teachers in Lithuania are often or permanently suffering from professional burnout.

More detailed descriptive statistics of the main research phenomenon are introduced below. Table 2 presents the correlation matrix, mean scores and standard deviations for all the main variables in the survey. As table 2 shows that professional burnout correlates positively with quantitative job demands, work pace as well as emotional demands at work. The results also show that the more university teachers receive social support from their 
colleagues and leaders the less burnout they feel. In addition, the more academicians are optimistic and feel efficient at work the less they suffer from burnout. All factors in demands group were positively related to each other as well as all factors in resources group. Quantitative and emotional demands were negatively related to all factors of resources.

Table 2

Descriptive statistics and correlation matrix for the main research variables

\begin{tabular}{lccccccccc}
\hline \multicolumn{1}{c}{ Variable } & Mean & SD & $\mathbf{1}$ & $\mathbf{2}$ & $\mathbf{3}$ & $\mathbf{4}$ & $\mathbf{5}$ & $\mathbf{6}$ & $\mathbf{7}$ \\
\hline $\begin{array}{l}\text { 1. Professional } \\
\text { burnout }(P B)\end{array}$ & 2.92 & .99 & & & & & & \\
\hline $\begin{array}{l}\text { 2. Quantitative } \\
\text { demands }(Q D)\end{array}$ & 3.95 & 1.20 & $.505^{*}$ & & & & & \\
\hline 3. Work pace (WP) & 5.01 & 1.25 & $.267^{*}$ & $.393^{*}$ & & & & \\
\hline $\begin{array}{l}\text { 4. Emotional } \\
\text { demands (ED) }\end{array}$ & 4.05 & 1.23 & $.429^{*}$ & $.442^{*}$ & $.406^{*}$ & & & \\
\hline $\begin{array}{l}\text { 5. Occupational } \\
\text { self-efficacy (OSE) }\end{array}$ & 5.63 & .78 & $-.350^{*}$ & $-.226^{*}$ & .066 & $-.225^{*}$ & & \\
\hline $\begin{array}{l}\text { 6. Optimism (O) } \\
\text { 7. Social support }\end{array}$ & 5.38 & .90 & $-.263^{*}$ & -.085 & .077 & $-.177^{*}$ & $.372^{*}$ & \\
$\begin{array}{l}\text { from colleagues } \\
\text { SSC) }\end{array}$ & 4.32 & 1.40 & $-.292^{*}$ & $-.165^{*}$ & .035 & $-.226^{*}$ & $.349^{*}$ & $.241^{*}$ \\
\hline $\begin{array}{l}\text { 8. Social support } \\
\text { rom a leader (SSL) }\end{array}$ & 3.44 & 1.11 & $-.169^{*}$ & $-.177^{*}$ & .003 & $-.269^{*}$ & $.298^{*}$ & $.227^{*}$ & $.506^{*}$ \\
\hline
\end{tabular}

Note: ${ }^{*}$ correlation is significant at the .01 level

$\mathrm{PB}$ - range from 1 till 5

QD; WP; ED; SSC, SSL - range from 1 till 6

OSE; O - range from 1 till 7

Linear regression analysis using a three-step enter method was employed for the main data analysis. In the first step only job demands were entered the model as predictors of professional burnout, in the second step personal resources were added and the final step included job resources as well.

Empirical data showed (see Figure 2 and Table 3) that regression models were statistically significant, and all predictors together explained 39.6 percent of professional burnout variance in the final model. It should be noted that $\mathrm{F}$ change was significant in each step of the linear regression analysis with entering method and $\mathrm{R}$ square increased with insertion of additional variables from .308 to .396 . 


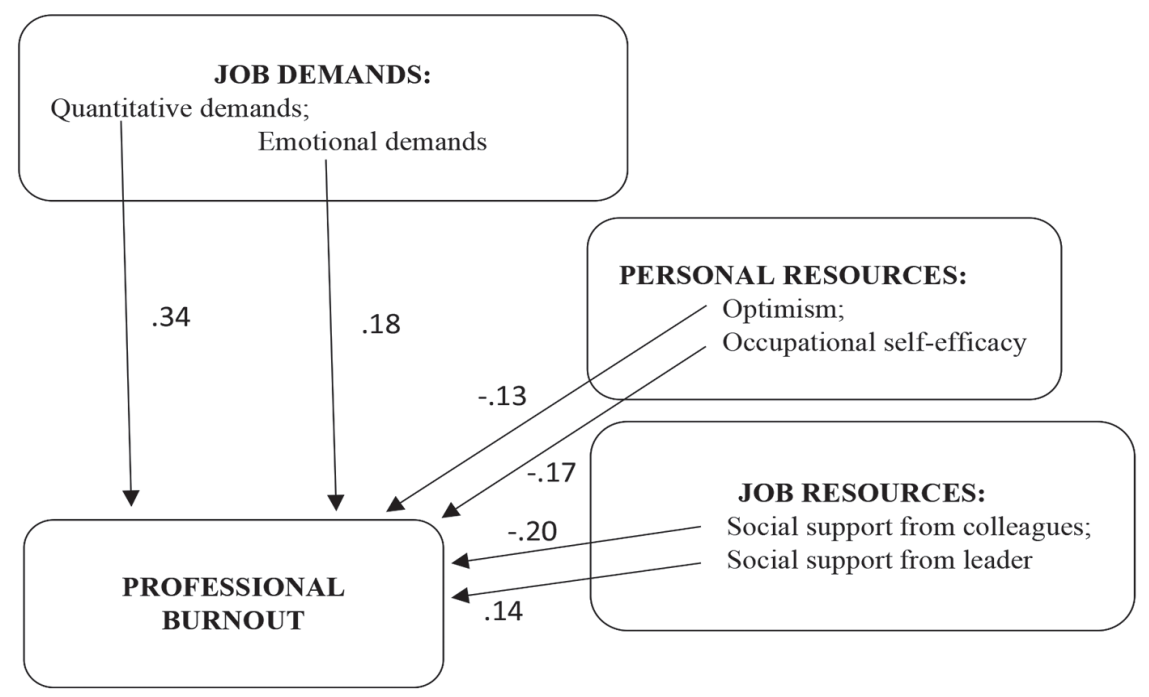

Figure 2. Risk and safety factors for the professional burnout among university teachers: empirical data

Note: numbers on the arrows - statistically significant standardized beta coefficients in the final integrated model; positive beta coefficients indicate risk factors for the professional burnout and negative ones - safety factors

Table 3

Results of the linear regression analysis: predicting professional burnout among university teachers

\begin{tabular}{|c|c|c|c|c|}
\hline Model & Predictors & $\begin{array}{c}\text { Standardized } \\
\text { coefficient Beta }\end{array}$ & $\mathbf{t}(\mathbf{p})$ & $\mathbf{F}(\mathbf{p})$ \\
\hline \multirow[t]{3}{*}{ Job demands } & Quantitative demands & .389 & $6.434(<.001)$ & \multirow{3}{*}{$\begin{array}{l}37.462 \\
(<.001)\end{array}$} \\
\hline & Work pace & .012 & $.196(.845)$ & \\
\hline & Emotional demands & .253 & $4.158(<.001)$ & \\
\hline \multirow{5}{*}{$\begin{array}{l}\text { Job demands + } \\
\text { Personal } \\
\text { resources }\end{array}$} & Quantitative demands & .339 & $5.743(<.001)$ & \multirow{5}{*}{$\begin{array}{l}29.781 \\
(<.001)\end{array}$} \\
\hline & Work pace & .085 & $1.446(.149)$ & \\
\hline & Emotional demands & .178 & $2.976(.003)$ & \\
\hline & Occupational self-efficacy & -.187 & $-3.30(.001)$ & \\
\hline & Optimism & -.140 & $-2.566(.11)$ & \\
\hline \multirow{7}{*}{$\begin{array}{l}\text { Job demands + } \\
\text { Personal } \\
\text { resources + } \\
\text { Job resources }\end{array}$} & Quantitative demands & .340 & $5.829(<.001)$ & \multirow{7}{*}{$\begin{array}{l}23.301 \\
(<.001)\end{array}$} \\
\hline & Work pace & .098 & $1.697(.091)$ & \\
\hline & Emotional demands & .176 & $2.921(.004)$ & \\
\hline & Occupational self-efficacy & -.168 & $-2.932(.004)$ & \\
\hline & Optimism & -.134 & $-2.480(.014)$ & \\
\hline & Social support from colleagues & -.195 & $-3.041(.003)$ & \\
\hline & Social support from leader & .141 & $2.187(.030)$ & \\
\hline
\end{tabular}


Quantitative demands were the major risk factor for the professional burnout among university teachers. More emotional demands at work also predicted stronger professional burnout. Personal resources (optimism and occupational self-efficacy) together with social support from colleagues acted as safety factors for professional burnout among university teachers. However, more social support from leader predicted stronger professional burnout among employees. Work pace was not a significant predictor of professional burnout.

\section{Discussion}

Recently in the modern labor market, work in the education system for its particularity (high work pace, abundance of information and different roles, lack of control and similar things) is attributed to the most stressful (Bulotaite et al., 2008; Puertas-Molero et al., 2018; Vesty et al., 2018; Xu, 2017). Therefore, this study aimed to evaluate the extent of university teachers' professional burnout problem in Lithuania and to identify the main risk and safety factors for the professional burnout of this sample. The findings of the cross-sectional survey confirmed the existence of the problem of professional burnout among university teachers in Lithuania. More than 40 percent of surveyed university teachers reported often or always experiencing signs of professional burnout. The obtained results, as well as other available research (e.g. Kebde, Gedfie, 2018; Lackritz, 2004; Toker, 2011; Visotskaya et al., 2015), support the assumption that university teachers' profession can be classified as the occupation of higher risk for burnout at work. Therefore, in order to find out how to deal with this problem, the identification of antecedents of professional burnout is of crucial importance.

It was hypothesized that both emotional and psychological job demands should be related with more professional burnout among the university teachers. In line with Berthelsen, Hakanen, Westerlund (2018), Bakker, Demerouti (2017), Baka (2015) and Dicke with colleagues (2018),results of this research revealed that quantitative and emotional demands predicted professional burnout among the university teachers: long lasting emotionally demanding interactions with students and a big amount of work to be done in a limited time were related with university teacher's state of physical, emotional and mental exhaustion. However, work pace was not a significant factor for the professional burnout in the education sector. We got only partial confirmation of the significance of psychological demands Kristensen with colleagues (2004) had mentioned: only extensity (number of working hours) not intensity (work pace) was important in predicting health impairment. Although the mean of work pace was the highest in comparison with other job demands aspects, it could be that possibilities to show the ability to work faster are associated with personal accomplishment (Vegchel et al., 2004) and are not associated with negative outcomes. In a multitasking era, this is quite common. 
An additional part of the hypothesis 1 stated that emotional demands should have a stronger effect on professional burnout. The results were opposite from what we expected from the literature analysis (Mudrak et al., 2018; Vegchel et al., 2004): quantitative demands had twice higher standardized beta coefficients in comparison with emotional demands while predicting professional burnout among university teachers. According to the mean scores of quantitative and emotional demands, university teachers experience both aspects of job demands. However, relationships with students are not only demanding, but also rewarding. It could be that emotional demands have both hindrance and challenging effect (Breevaart, Bakker, 2018) that should be tested in future research. Besides, the perception of emotional demands could be more subjective than the perception of quantitative demands and its' impact on a state of exhaustion could vary among individuals. With reference to the results, a mismatch between the amount of work and available time for it (quantitative demands) could be defined as the main risk factor for the professional burnout among university teachers. These findings are in line with Gallup study of nearly 7,500 full-time employees, indicating five top factors related to burnout: unfair treatment at work, unmanageable workload, lack of role clarity, lack of communication and support from the manager, unreasonable time pressure (Wigert, Agraval, 2018).

Our second hypothesis held, that higher levels of personal resources, i.e. optimism and occupational self-efficacy, were related to lower levels of professional burnout among university teachers. In our study personal resources (optimism and occupational selfefficacy) acted as safety factors for professional burnout among university teachers. These findings come in line with studies by Barkhuizen and colleagues (2014), who also noted the negative and direct impact of optimism on burnout among university teachers in South Africa (more optimism, less burnout). Similar findings were reported by $\mathrm{Pu}$ and colleagues from China (2017). A recent study with undergraduate students also suggested thatoptimism is a personal resource helping to prevent academic burnout (Vizoso, Arias-Gundín, Rodríguez, 2019). These findings show that optimism is a recognized personal resource, which still needs more exploration, especially in academic staff context. Occupational self-efficacy is also named as a personal resource. Lower perceived self-efficacy was related to higher burnout among teachers in a study carried out by Friedman (2003) and Schwarzer, Hallum (2008). Our study confirmed literature findings of occupational self-efficacy as a protective factor for professional burnout among university teachers as well. Prognostic value of both optimism and occupational self-efficacy was quite similar although one factor was more general and the other one more related to the specific work setting.

The third hypothesis was about job resources and held that social support from colleagues and leader were related to lower levels of professional burnout among university teachers. The hypothesis was confirmed only partially - social support from colleagues acted as a safety factor for professional burnout among university teachers, which was not the case with leaders: social support from a leader predicted stronger professional burnout among 
employees. The latter relationship might be associated with Social Exchange Theory, where social support, received from a supervisor, may lead "to a felt obligation to help the organization, as well as the expectation that increased performance on behalf of the organization will be noticed and rewarded" (Kurtessis, et al., 2015, 3). It is possible, that subordinates may have misunderstood the intentions of social support from a supervisor and the emerged obligation may have induced a strong commitment to an organization probably followed by a more eager involvement in everyday tasks. On the other hand, Kurtessis and colleagues (2015) suggest supervisor support may vary depending on different styles of leadership, but these assumptions need further exploration. However, in line with AbuAlRub (2004) and Rothmann, Essenko (2007), social support from colleagues was a significant safety factor for the professional burnout among university teachers in Lithuania.

Practical implications. The present findings of this study may have significant implications for practice. First of all, the results of the study revealed that one of the greatest challenges to avoiding burnout among university teachers is quantitative job demands. Unfortunately, in today's higher education system, a person has little power to reduce workload. Therefore, this task should be taken by university human resources managers to offer time planning training for employees. Secondly, in the light of the finding related to emotional demands, it is worth considering giving teachers more emotional support as well as encouraging them to engage in personally pleasing activities or hobbies, exercises. This would help to relieve the entire emotional burden of constant communication with students. Besides of that, the personal resources of university teachers can also serve to reduce their burnout at work. Human resource managers should try to create a university working environment that enhances employee optimism and occupational self-efficacy (for example, setting reasonable goals and expectations, ensuring appropriate job demands, creating transparent and reliable communication, etc.) as well as to promote communality and social support between university teachers. They should also work with leaders and their skills to give sustaining sincere social support to their employees without pressure to work harder in return. Involving leaders in burnout prevention is also stressed by Gallup study (Wigert, Agraval, 2018), moreover, the study points to the alignment of both manager and organization, shifting the responsibility for employee's health and well-being from the employee him/herself to the organization.

Limitations. As with every study, the present one is not without limitations. First of all, only employees' self-reports were used in the research. It could cause the problem of common method variance. However, self-reports served us for the assessment of the relationships between perceived demands, resources and burnout. Perception of employees (university teachers) was the key object of the research: subjective perception of risk and safety factors for the professional burnout was more interesting than an objective reality. Secondly, our cross-sectional survey design allows talking only about relational links between the analyzed phenomena. Longitudinal data would be very useful in order to 
establish causality between job demands, resources and professional burnout. Finally, the general measure of professional burnout (widely used scale from COPSOQ) was applied in the research. So, different aspects of exhaustion (e.g. physical, emotional and mental) can't be analyzed separately. However, this time the main focus in the research was on the variety of risk and safety factors for the strain symptom - burnout in general. Therefore, the choice of the instrument was consistent with the research idea.

Directions for future research. There are some additional issues to be addressed by further research in the area of risk and safety factors of professional burnout among university teachers. With regard to protective factors of professional burnout more attention should be given to analysis of additional job resources more specific to university teachers. Further research should also take into notice a wider pool of personal factors that could extend a reservoir of sustaining resources for university teachers. Job demands for university teachers may also be different from that of other service personnel, so it would be beneficial to research more into psychosocial work-related stressors in relation to burnout. As university staff comprises not only teachers, other university personnel, which might have different work-related challenges, should also be studied. It would also be useful to compare resources as well as job demands and their impact on professional burnout in different professional groups.

\section{Conclusions}

The proposed theoretical model suggests the inclusion of job demands (quantitative and emotional demands, work pace) as risk factors, and personal (optimism and occupational self-efficacy) and job (social support from colleagues and leader) resources as safety factors having an impact for professional burnout.

With reference to empirical data of the cross-sectional survey, it can be stated that:

- 42.8 percent of university teachers in Lithuania are often or permanently suffering from professional burnout;

- a mismatch between the amount of work and available time for it (quantitative demands) could be defined as the main risk factor for the professional burnout among university teachers. Higher emotional demands (sustained emotional efforts during the interaction with clients) also significantly predicted stronger professional burnout;

- personal resources (optimism and occupational self-efficacy) alongside with social support from colleagues acted as safety factors for professional burnout among university teachers. On the contrary, higher perceived social support from a supervisor predicted stronger professional burnout among university teachers in Lithuania. 
Future research should try to explain controversial results, broaden the pool of risk and safety factors for professional burnout among university teachers, include a comparison of other samples and implement longitudinal data in order to evaluate causality effects.

The main recommendations how to deal with the problem of professional burnout among university teachers are directed to human resource managers that are proposed with particular actions (e.g. time planning trainingfor employees, leader training about social support offering particularities, interventions to a working environment, etc.).

\section{References}

AbuAlRub, R. F. (2004). Job Stress, Job Performance, and Social Support among Hospital Nurses. Journal of Nursing Scholarship, 36(1), 73-78.

Antoniou, A.-S., Ploumpi, A., \& Ntalla, M. (2013). Occupational Stress and Professional Burnout in Teachers of Primary and Secondary Education: The Role of Coping Strategies. Psychology, 4(3A), 349-355.

Azeem, S. M., \& Nazr, N. A (2008). A Study of Job Burnout among University Teachers. Psychology and Developing Societies, 20(1), 51-64.

Baka, L. (2015). Does Job Burnout Mediate Negative Effects of Job Demands on Mental and Physical Health in a Group of Teachers? Testing The Energetic Process of Job Demands-Resources Model. International journal of occupational medicine and environmental health, 28(2), 335.

Bakker, A. B., \& Demerouti, E. (2014). Job Demands-Resources Theory. Wellbeing: A complete reference guide, $1-28$.

Bakker, A. B., \& Demerouti, E. (2017). Job Demands-Resources Theory: Taking Stock and Looking Forward. Journal of Occupational Health Psychology, 22(3), 273.

Bakker, A. B., \& Demerouti, E. (2018). Multiple Levels in Job Demands-Resources Theory:

Implications for Employee Well-being and Performance. Handbook of well-being.

Bakker, A. B., Demerouti, E., \& Euwema, M. C. (2005). Job Resources Buffer the Impact of Job

Demands on Burnout. Journal of Occupational Health Psychology, 10(2), 170-180.

Barkhuizen, N., \& Rothmann, S. (2008). Occupational Stress of Academic Staff in South African

Higher Education Institutions. South African Journal of Psychology, 38, 321-336.

Barkhuizen, N., Rothmann, S., \& van de Vijver, F. J. (2014). Burnout and Work Engagement of

Academics in Higher Education Institutions: Effects of Dispositional Optimism. Stress and Health, 30, 322-332.

Berthelsen, H., Hakanen, J. J., \& Westerlund, H. (2018). Copenhagen Psychosocial Questionnaire-a

Validation Study Using The Job Demand-resources Model. PloS one, 13(4), e0196450.

Breevaart, K., \& Bakker, A. B. (2018). Daily job Demands and Employee Work Engagement: The Role of Daily Transformational Leadership Behavior. Journal of occupational health psychology, 23(3), 338 . 
Bulotaite, L., Bliumas, R. ir Pociūtè, B. (2015). Peculiarities of Work and Stress of University Teachers. Acta Paedagogica Vilnensia, 21, 208-219.

Carver, C. S., \& Scheier, M. F. (2014) Dispositional Optimism. Trends in Cognitive Sciences, 18(6), 293-299.

de Heus, P., \& Diekstra, R. F. W. (1999). Do Teachers Burn out More Easily? A Comparison of Teachers with Other Social Professions on Work Stress and Burnout Symptoms. In R. Vandenberghe \& A. M. Huberman (Eds.), Understanding and Preventing Teacher Burnout: A Sourcebook of International Research and Practice (pp. 269-284). New York, NY, US: Cambridge University Press.

Dicke, T., Stebner, F., Linninger, C., Kunter, M., \& Leutner, D. (2018). A Longitudinal Study of Teachers' Occupational Well-being: Applying the Job Demands-Resources Model. Journal of occupational health psychology, 23(2), 262.

Diener, E., Heintzelman, S. J., Kushlev, K., Tay, L., Wirtz, D., Lutes, L. D., \& Oishi, S. (2017). Findings All Psychologists Should Know From The New Science on Subjective Wellbeing. Canadian Psychology/psychologie canadienne, 58(2), 87.

Friedman, I. A. (2003). Self-efficacy and Burnout in Teaching: The Importance of Interpersonalrelations Efficacy. Social Psychology of Education: An International Journal, 6(3), 191-215.

Harrison, B. J. (1999). Are You Destined to Burn out? Fund Raising Management, 30(3), 25-27.

Herzberg, P. Y., Glaesmer, H., \& Hoyer, J. (2006). Separating Optimism and Pessimism: A Robust Psychometric Analysis of The Revised Life Orientation Test (LOT-R). Psychological assessment, 18(4), 433.

Hobfoll, S. E. (2002). Social and Psychological Resources and Adaptation. Review of General Psychology, 6, 307-324.

Hobfoll, S. E., Halbesleben, J., Jean-Pierre Neveu, J-P., \& Westman, M. (2018). Conservation of Resources in the Organizational Context: The Reality of Resources and Their Consequences. Annu. Rev. Organ. Psychol. Organ. Behav, 5, 103-128.

Ishaq, R., Mahmood, A. (2017). Relationship between Job Stress and Employee Burnout-The Moderating Role of Self-Efficacy for University Teachers. Journal of Research and Reflections in Education, 11(2), 100-112.

Johnson, S., Cooper, C., Cartwright, S., Donald, I., Taylor, P., \& Millet, C. (2005). The Experience of Work-related Stress Across Occupations. Journal of Managerial Psychology, 20(2), 178-187.

Karatepe, O. M. (2015) "Do Personal Resources Mediate the Effect of Perceived Organizational Support on Emotional Exhaustion and Job Outcomes?", International Journal of Contemporary Hospitality Management, 27(1), 4-26.

Kebde, A., \& Gedfie, M. (2018). Burnout Experience among Public Universities of Amhara Regional State, Ethiopia. Indian Journal of Health \& Wellbeing, 9(8/9), 929-940.

Kristensen, T. S., Bjorner, J. B., Christensen, K. B., \& Borg, V. (2004). The Distinction between Work Pace and Working Hours in the Measurement of Quantitative Demands at Work. Work \& stress, 18(4), 305-322. 
Kurtessis, J. N., Eisenberger, R., Ford, M. T., Buffardi, L. C., Stewart, K. A. \& Adis, C. S. (2015). Perceived Organizational Support a Meta-Analytic Evaluation of Organizational Support Theory. Journal of Management, 31, 874-900.

Lath, S. K. (2010). An Assortment Aspect of The Stress among School Teachers. International Journal of Educational Administration, 2(2), 433-41.

Lent, R. W. (2005). A Social Cognitive View of Career Development and Counseling. In S. D. Brown \& R. W. Lent (Eds.), Career Development and Counseling: Putting Theory and Research to Work. (pp. 101-130). New York: Wiley.

Maslach, C., \& Leiter, M. (1999). Teacher Burnout: A Research Agenda. In R. Vandenberg \& A. Huberman (Eds.), Understanding and Preventing Teacher Burnout (pp. 295-303). Cambridge: Cambridge University Press.

Mudrak, J., Zabrodska, K., Kveton, P., Jelinek, M., Blatny, M., Solcova, I., \& Machovcova, K. (2018). Occupational Well-being Among University Faculty: A Job Demands-Resources Model. Research in Higher Education, 59(3), 325-348.

Pociūtè, B., Bulotaite, L. ir Bliumas, R. (2012). Job Satisfaction, Work Values and Stress in University Teachers. Acta Paedagogica Vilnensia, 28, 37-48.

Pu, J., Hou, H., Ma, R., \& Sang, J. (2017). The Effect of Psychological Capital between Workfamily Conflict and Job Burnout in Chinese University Teachers: Testing for Mediation and Moderation. Journal of Health Psychology, 22(14), 1799-1807.

Puertas-Molero, P., Zurita-Ortega, F., Chacón-Cuberos, R., Martínez-Martínez, A., CastroSánchez, M., \& González-Valero, G. (2018). An Explanatory Model of Emotional Intelligence and Its Association with Stress, Burnout Syndrome, and Non-Verbal Communication in the University Teachers. Journal of Clinical Medicine, 7, pii: E524.

Rigotti, T., Schyns, B., \& Mohr, G. (2008). A Short Version of the Occupational Self-efficacy Scale: Structural and Construct Validity Across Five Countries. Journal of Career Assessment, 16(2), 238-255.

Rothmann, S., \& Essenko, N. (2007) Job Characteristics, Optimism, Burnout, and Ill Health of Support Staff in a Higher Education Institution in South Africa. South African Journal of Psychology, 37(1), 135-152.

Rupert, P. A., Miller, A. O., \& Dorociak, K. E. (2015). Preventing Burnout: What does the Research Tell Us?. Professional Psychology: Research and Practice, 46(3), 168.

Salvagioni, D. A. J., Melanda, F. N., Mesas, A. E., Gonza'lez, A. D., Gabani, F. L., \& Andrade, S. M. (2017). Physical, Psychological and Occupational Consequences of Job Burnout: A Systematic Review of Prospective Studies. PLoS ONE, 12(10), e0185781.

Schaufeli, W. B., \& Enzmann, D. (1998). The Burnout Companion to Study and Practice: A Critical Analysis. Philadelphia: Taylor \& Francis.

Schaufeli, W. B., \& Greenglass, E. R. (2001). Introduction to Special Issue on Burnout and Health. Psychology and Health, 16, 501-510.

Schvarzer, R., \& Hallum, S. (2008) Perceived Teacher Self-Efficacy as a Predictor of Job Stress and Burnout: Mediation Analyses. Applied Psychology: An International review, 57, 152-171. 
Schyns, B., \& Wolfram, H. J. (2008). The Relationship Between Leader-member Exchange and Outcomes as Rated by Leaders and Followers. Leadership \& Organization Development Journal, 29(7), 631-646.

Shen, B., McCaughtry, N., Martin, J., Garn, A., Kulik, N., \& Fahlman, M. (2015). The Relationship Between Teacher Burnout and Student Motivation. British Journal of Educational Psychology, 85(4), 1-14.

Speier, C., \& Frese, M. (1997). Generalized Self Efficacy as a Mediator and Moderator Between Control and Complexity at Work and Personal Initiative: A Longitudinal Field Study in East Germany. Human performance, 10(2), 171-192.

Swider, B. W., \& Zimmerman, R. D. (2010). Born to Burnout: A Meta-Analytic Path Model of Personality, Job Burnout, and Work Outcomes. Journal of Vocational Behavior, 76 (3), 487-506.

Toker, B. (2011). Burnout Among University Academicians: an Empirical Study on The Universities of Turkey. Doğuş Üniversitesi Dergisi, 12(1), 114-127.

Upadyaya, K., Vartiainen, M., \& Salmela-Aro, K. (2016). From Job Demands and Resources to Work Engagement, Burnout, Life Satisfaction, Depressive Symptoms, and Occupational Health. Burnout Research, 3, 101-108.

Vaananen, A., Toppinen-Tanner, S., Kalimo, R., Mutanen, P., Vahtera, J., \& Peiro, J. M. (2003). Job Characteristics, Physical and Psychological Symptoms, and Social Support as Antecedents of Sickness Absence Among Men and Women in The Private Industrial Sector. Social Science \& Medicine, 57, 807-824.

Vegchel, N. V., Jonge, J. D., Söderfeldt, M., Dormann, C., \& Schaufeli, W. (2004). Quantitative Versus Emotional Demands among Swedish Human Service Employees: Moderating Effects of Job Control and Social Support. International Journal of Stress Management, 11(1), 21.

Vesty, G., Sridharan, V. G., Northcott, D., \& Dellaportas, S. (2018). Burnout Among University Accounting Educators in Australia and New Zealand: Determinants and Implications. Accounting \& Finance, 58(1), 255-277.

Vizoso, C., Arias-Gundín, O. \& Rodríguez, C. (2019). Exploring Coping and Optimism as Predictors of Academic Burnout and Performance Among University Students. Educational Psychology.

Xanthopoulou, D., Bakker, A. B., Demerouti, E., \& Schaufeli, W. B. (2007). The Role of Personal Resources in the Job Demands-Resources Model. International Journal of Stress Management, $14(2), 121-141$.

Xu, L. (2017) Teacher-Researcher Role Conflict and Burnout among Chinese University Teachers: a Job Demand-Resources Model Perspective, Studies in Higher Education.

Watts, J., \& Robertson, N. (2011). Burnout in University Teaching Staff: A Systematic Literature Review. Educational Research, 53(1), 33-50.

Wigert, B., \& Agraval, S. (2018). Employee Burnout, Part 1: The 5 Main Causes. Workplace, July $12,2018$. 